\title{
Lacustrine Fossil Preservation in Acidic Environments: Implications of Experimental and Field Studies for the Cretaceous-Paleogene Boundary Acid Rain Trauma
}

\author{
JAKE V. BAILEY* and ANDREW S. COHEN \\ Department of Geosciences, University of Arizona, Tucson, AZ 85721-0077; E-mail:jvbailey@usc.edu \\ DAVID A. KRING \\ Department of Planetary Sciences, Lunar and Planetary Laboratory, University of Arizona, Tucson, AZ 85721
}

PALAIOS, 2005, V. 20, p. 376-389 DOl 10.2110/palo.2003.p03-88

The effects of acidification on the preservation of buried lacustrine microfossils were evaluated using experimental tanks to simulate $\mathrm{pH}$, depth, duration of acidification, and buffering conditions below the sediment / water interface of a hypothetical acidified lake. The taphonomic data provided from these experiments suggest that buffering by the host catchment (i.e., the $\mathrm{CaCO}_{3}$ content of the soils and outcrops that underlie the lake and drainage basin) is the primary factor promoting calcareous-fossil preservation under conditions of moderate and severe acidification.

Global acid-rain fallout was a likely environmental consequence of the Chicxulub impact event at the CretaceousPaleogene boundary, and may have been important at other times in Earth history. Fossil preservation at the $\mathrm{K} / \mathrm{Pg}$ boundary may have been affected by acidic groundwater leaching. Whereas the duration and intensity of the acidrain fallout is poorly constrained, acid rain would have had varying effects on the acidity of lacustrine and fluvial environments with different acid-buffering capacities. Variations in acid-buffering capacities of lacustrine and fluvial catchments also may be a factor in the apparent extinction selectivity of non-marine aquatic fauna at the K/Pg boundary. Last appearances of taxa can result from poor preservation conditions or extinction - both of which may result from acidification. Last appearances observed at the species level, but not in higher taxa, may be the result of regional heterogeneities in catchment geology. Understanding local buffering conditions may be important for interpreting the continental fossil record at the K/Pg boundary.

\section{INTRODUCTION}

From a paleontological perspective, water-body acidification is an environmental condition with demonstrated biological effects and the potential to cause ecosystem stresses (e.g., Wright et al., 1975; Schindler et al., 1985; Rosseland, 1986; Schindler, 1988). Acidification also can be viewed as a destructive taphonomic mechanism whereby calcareous shells and skeletons are selectively dissolved by acidic waters or sediments (e.g., Linse, 1992;

\footnotetext{
* Current address: Department of Earth Sciences, University of Southern California, Los Angeles, CA 90089-0740
}

Copyright $\odot$ 2005, SEPM (Society for Sedimentary Geology)
Clayburn et al., 2004). Surface-water acidification can occur through the deposition of strong acids from the atmosphere (e.g., Driscoll et al., 2001). It also can result from the oxidation of sulfide minerals, such as pyrite $\left(\mathrm{FeS}_{2}\right)$, or by the activity of organic acids in humid climates (e.g., Likens et al., 1972). Various biological effects, such as fish kills, have been attributed to modern water-body acidification in lakes of Canada, Europe, and the eastern United States (Beamish, 1976; Muniz et al., 1978; Baker and Schofield, 1982; Battarbee, 1984; Charles, 1985; Freda, 1986; Hartmann and Steinberg, 1986; Rhenberg et al., 1990). Acidification also results in effects such as metal leaching in lakes with low alkalinity (poorly buffered lakes) and calcium carbonate whitings in lakes with high alkalinities (well-buffered lakes) (Lajewski et al., 2003).

Whereas local acidification can occur from sulfide weathering and organic-acid accumulation, regional or global acidification requires a substantial atmospheric perturbation of acid-forming chemical species. Large volcanoes (Pinto et al., 1989) and impacting asteroids or comets (Lewis et al., 1982; Prinn and Fegley, 1982; Brett, 1992; Kring et al., 1996) are capable of producing such perturbations and were likely primary sources of acid-forming aerosols and gasses capable of producing regional or global acid-rain fallout and lake acidification in the geologic past.

Perhaps the best-known and paleontologically significant acid-forming event is the Chicxulub impact, which cooccurred with the $\mathrm{K} / \mathrm{Pg}$ mass extinction (Alvarez et al., 1980; Bohor et al., 1984; Kring et al., 1991; Hildebrand et al., 1991). The Chicxulub impact is widely thought to have produced both nitric-acid and sulfuric-acid rain. Acid was produced from vaporized material excavated from Earth's crust, the obliterated asteroid or comet, and interactions of this material with the atmosphere (Lewis et al., 1982; Prinn and Fegley, 1982; Brett, 1992).

The Chicxulub impact event occurred on a shallow-marine shelf that included a 3-km-thick sequence of carbonates and evaporites (primarily anhydrite). Vaporized anhydrite $\left(\mathrm{CaSO}_{4}\right)$ is thought to have introduced sulfate aerosols into the stratosphere (Brett, 1992; Sigurdsson et al., 1992; Pope et al., 1994; Ivanov et al., 1996; Pierazzo et al., 1998; Yang and Ahrens, 1998). Estimates of the mass of S vary (Table 1), ranging from $4 \times 10^{16}$ to $4.3 \times 10^{18} \mathrm{~g}$, based on simple scaling models (Brett, 1992; Sigurdsson et al., 1992; Kring, 1993). However, recent computer simulations of the impact event suggest values of $7.5 \times 10^{16}$ to 0883-1351/05/0020-0376/\$3.00 
TABLE 1-Estimates of the amount of sulfur generated from target materials at the Chicxulub impact site and ejected into the stratosphere.

\begin{tabular}{lcrr}
\hline \hline \multicolumn{1}{c}{ Study } & Mass S (g) & Production of $\mathrm{H}_{2} \mathrm{SO}_{4}$ (moles) & $\begin{array}{c}\text { Global acid fluence } \\
\text { (keq/ha) }\end{array}$ \\
\hline Brett, 1992 & $2 \times 10^{17}$ & $2 \times 10^{15}$ & 40 \\
Sigurdsson et al., 1992 & $1.3 \times 10^{18}$ to $4.3 \times 10^{18}$ & $1.3 \times 10^{16}$ to $4.3 \times 10^{16}$ & $4 \times 10^{14}$ to $4 \times 10^{16}$ \\
Kring, 1993 & $4 \times 10^{16}$ to $4 \times 10^{18}$ & $5.2 \times 10^{14}$ to $6.1 \times 10^{15}$ & 5 to 850 \\
Chen et al., 1994 & $9.0 \times 10^{16}$ to $6.0 \times 10^{17}$ & $5 \times 10^{14}$ to $1.9 \times 10^{15}$ & 18 to 120 \\
Ivanov et al., 1996 & $5 \times 10^{16}$ to $1.8 \times 10^{17}$ & $7.7 \times 10^{14}$ to $2.3 \times 10^{15}$ & 10 to 37 \\
Pierazzo et al., 1998 & $7.5 \times 10^{16}$ to $2.3 \times 10^{17}$ & $5 \times 10^{14}$ to $2 \times 10^{15}$ & 15 to 46 \\
Yang and Ahrens, 1998 & $5 \times 10^{16}$ to $2 \times 10^{17}$ & $5.6 \times 10^{13}$ to $2.0 \times 10^{14}$ & 10 to 40 \\
Gupta et al., 2001 & $5.5 \times 10^{15}$ to $2.0 \times 10^{16}$ & & 1 to 4 \\
\hline
\end{tabular}

$6.0 \times 10^{17} \mathrm{~g} \mathrm{~S}$, producing a total of $7.7 \times 10^{14}$ to $6.1 \times 10^{15}$ moles of $\mathrm{H}_{2} \mathrm{SO}_{4}$ and a globally distributed deposition of 10 to 120 molar kiloequivalents per hectare (keq/ha). For comparison with modern industrial deposition of anthropogenic sulfur, Battarbee et al. (1996) report acidification of several northern European lakes at sulfur oxide deposition rates of 0.44 to $2.21 \mathrm{keq} / \mathrm{ha} / \mathrm{yr}$. Additional S likely was injected from the obliterated asteroid or comet (Kring et al., 1996), but this would have been a small contribution relative to that from the anhydrite (Kring, 2003). A modelderived estimate of $\sim 5 \times 10^{15} \mathrm{~mol}$ of sulfuric acid (Pierazzo et al., 1998) is consistent with the observed cation concentration of leached $\mathrm{K} / \mathrm{Pg}$ boundary soils (Retallack, 1996), enhanced continental weathering suggested by the ${ }^{87} \mathrm{Sr} /{ }^{86} \mathrm{Sr}$ record (MacDougall, 1988; Vonhof and Smit, 1997; MacLeod et al., 2001; for a different viewpoint, see MacArthur et al., 1998), etching of $\mathrm{K} / \mathrm{Pg}$ spinel crystals (Preisinger et al., 2002), and low C/S ratios in terrestrial $\mathrm{K} / \mathrm{Pg}$ boundary sediments (Maruoka et al., 2002).

Computer simulations of the vapor-rich impact-ejecta plume indicate material was deposited in the atmosphere in all areas of the globe, although there were areas with slightly more fallout material (Argyle, 1989; Melosh et al., 1990; Kring and Durda, 2002). The antipode, for example, received $\sim 3.9$ times more mass of high-energy ejecta, and thus sulfur, than did Europe (Kring and Durda, 2002).

The production of nitric-acid rain also has been proposed as an environmental consequence of the $\mathrm{K} / \mathrm{Pg}$ impact (Lewis et al., 1982; Prinn and Fegley, 1987). Reentering high-energy impact ejecta is thought to have shockheated the atmosphere, resulting in the formation of $\sim 1 \times$ $10^{15}$ mol nitric-acid rain (Zahnle, 1990). Heating of the atmosphere likely generated wildfires (Melosh et al., 1990; Kring and Durda, 2002), which may have produced an additional $\sim 3 \times 10^{15} \mathrm{~mol}$ of nitric-acid rain (Crutzen, 1987). Models suggest that over a period of several months to perhaps a few years (Prinn and Fegley, 1987; Pope et al., 1994; Kring et al., 1996; Pierazzo et al., 1998, 2003), acidic material would have settled to the troposphere, where it promptly would have rained out, potentially acidifying shallow-water ecosystems.

D'Hondt et al. (1994) calculated that globally uniform, rapid deposition of the lowest estimates of acid would have had no major effects on sea-surface chemistry, while the highest estimates would have destroyed the carbonatebuffering capacity of the top $100 \mathrm{~m}$ of the world ocean. As a result of the much more variable chemistry of lakes and streams, the responses of inland waters to post-impact acid rain would have been more complex. Factors such as catchment bedrock geology, surficial sediment geology, local acid-precipitation conditions, and hydrological conditions would have created many different responses to acid deposition (e.g., Eilers and Selle, 1991). Alkalinity (or acidneutralizing capacity), which is derived principally from the action of the carbonate and bicarbonate ions, is highly dependent on the weathering characteristics of local bedrock and sediments (Ulrich, 1983; Brakke and Loranger, 1986; Eilers et al., 1987; Munson and Gherini, 1991; Bluth and Kump, 1994). Bodies of water in catchments containing easily weathered carbonate-rich bedrock and sediments have much higher alkalinities than those containing granitic bedrock or siliciclastic sediments, and would have been less susceptible to acidification. Buffering reactions in a lake's drainage basin also are limited by the rate at which weathering reactions can occur (Schnoor and Stumm, 1985). Catchments with limestone outcrops (Fig. 1) and calcareous soils yield the highest reaction rates in the Goldich series (Goldich, 1938); for example the reaction:

$$
\mathrm{H}_{2} \mathrm{SO}_{4}+2 \mathrm{CaCO}_{3} \rightarrow 2 \mathrm{HCO}^{3-}+2 \mathrm{Ca}^{2+}+\mathrm{SO}_{4}^{2-}
$$

has very high reaction rates, and can consume hydrogen ions from acid rain in the catchment before they reach the lake itself.

Acidification in granitic and other siliciclastic terrains (e.g., Likens et al., 1972) occurs because weathering reaction rates for feldspars, biotite and muscovite, aluminum oxides, and quartz show progressively slower reaction rates along the Goldich dissolution series. Figure 2 shows the primary interactions that occur when acid rain from various impact-generated sources interacts with granitic drainage basins. An example of the weathering reactions occurring in granitic terrains is that of orthoclase and sulfuric acid:

$$
\begin{aligned}
\mathrm{H}_{2} \mathrm{SO}_{4} & +9 \mathrm{H}_{2} \mathrm{O}+2 \mathrm{KAlSi}_{3} \mathrm{O}_{8} \rightarrow 4 \mathrm{H}_{4} \mathrm{SiO}_{4}+2 \mathrm{~K}^{+} \\
& +\mathrm{SO}_{4}^{2-}+\mathrm{Al}_{2} \mathrm{Si}_{2} \mathrm{O}_{5}(\mathrm{OH})_{4}
\end{aligned}
$$

a reaction that slowly buffers acid rain by consuming hydrogen ions and releasing basic cations along with silicic acid. During periods of high acid precipitation, slow weathering reactions in granitic terrains limit the amount of acid neutralized. Non-neutralized acidic runoff can acidify lakes and streams, kill aquatic animals, and dissolve surficial and buried calcareous skeletons. Depositional settings that also contain acid-producing vegetation often have naturally acidic sediments, and would have 


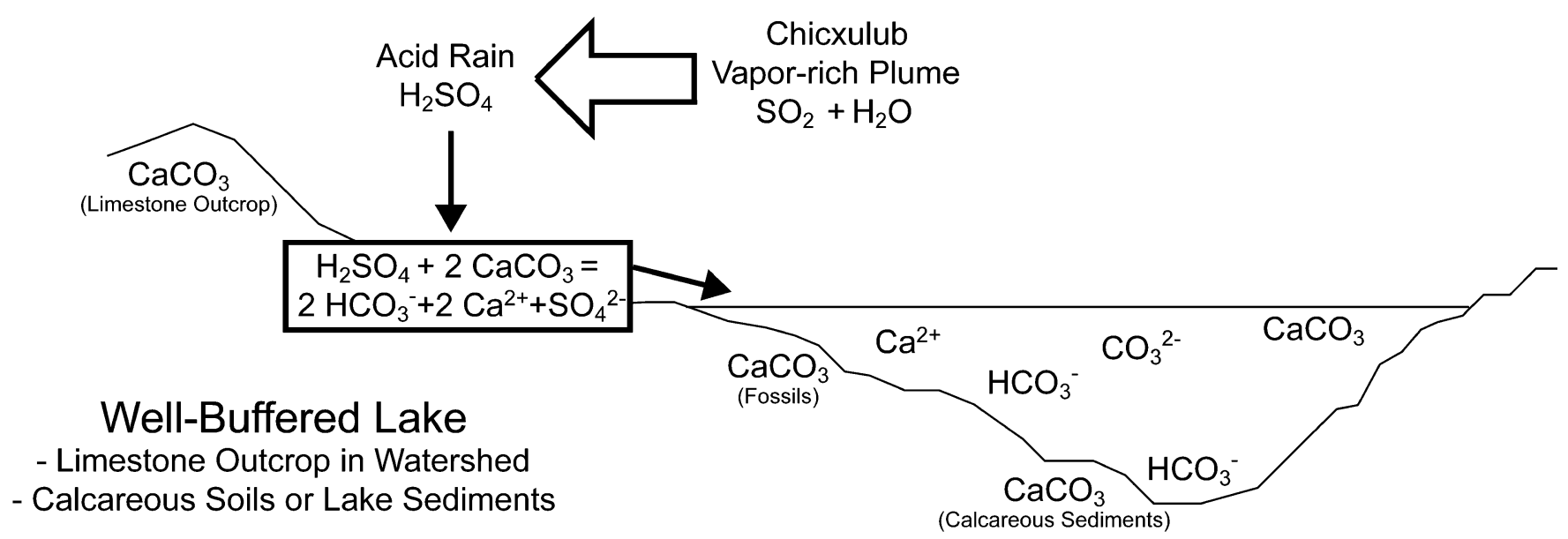

FIGURE 1-Impact-generated acid deposition and its chemical effects on a carbonate-rich lake drainage basin. Acid deposition is unlikely to cause fossil dissolution in such a setting. Modified after Schnoor and Stumm, 1985 and Lajewski et al., 2003.

been poorly buffered against further acidification (Schnoor and Stumm, 1985).

Since acidic groundwater has the capacity to dissolve calcareous remains already deposited in basin sediments prior to the impact, basin-wide responses to acid rain, which influence localized burial conditions, may have determined the preservation potential of non-marine shelly material at and below the K/Pg boundary. One possible effect of acid dissolution of calcareous material is to produce preservational, rather than biological, last appearances for certain shelled taxa, further confounding the interpretation of fossil records below impact horizons. Interpretation of impact horizon biostratigraphy already is complicated by a combination of fossil reworking, sampling effects, and random fossil distributions (e.g., Signor and Lipps, 1982). Because of the potential leaching of calcareous fossils by acidic groundwater, the usefulness of lacustrine microfossils as indicators of change brought about by the $\mathrm{K} / \mathrm{Pg}$ acid trauma needs to be determined as a function of their preservation potential under high acid-stress conditions.

This paper focuses on determining the effects of localized acidic burial conditions on preservation of calcareous material using an experimental-taphonomy approach. The experiments reported on here test the effects of hostsediment carbonate buffering, pore-water $\mathrm{pH}$, depth of burial, and duration of contact with acidic waters on ostracode carapaces. The experimental taphonomy data presented are used to make predictions about the preservation of microfossils in various depositional environments across the $\mathrm{K} / \mathrm{Pg}$ boundary. The results of field microfossil sampling in eastern Montana are presented alongside the experimental taphonomy results as a first step in attempting to test preservation models using data from the rock record. Also discussed in this paper are basin-scale factors that may have controlled acidification, such as the potential irrigating effect of burrows, the preservation potential of known terrestrial $\mathrm{K} / \mathrm{Pg}$ boundary localities, and impli-

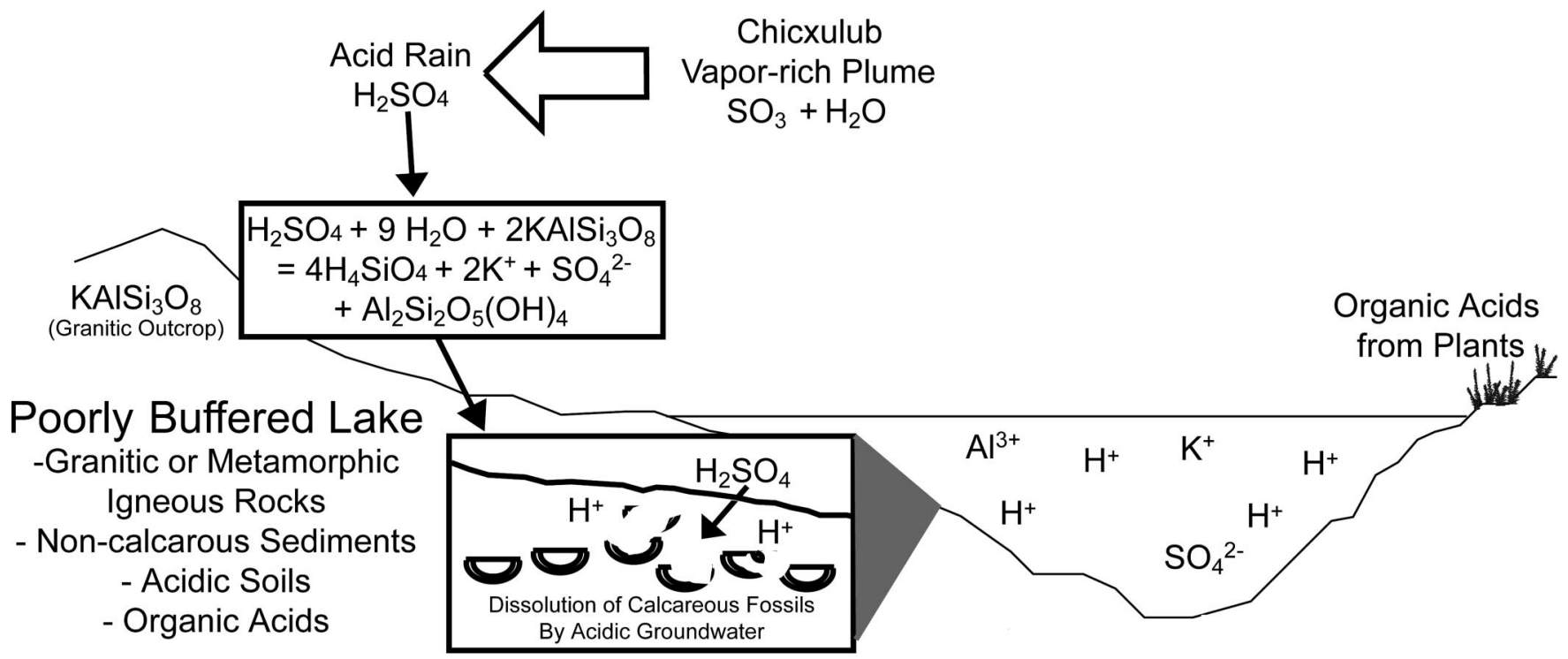

FIGURE 2-Impact-generated acid deposition and its chemical effects on a granitic lake drainage basin. Acid deposition can cause lake acidification and leaching of fossil material by acidic groundwater. Modified after Schnoor and Stumm, 1985 and Lajewski et al., 2003. 
cations for selective organism survival and fossil preservation at the $\mathrm{K} / \mathrm{Pg}$ boundary.

\section{OSTRACODES AS EXPERIMENTAL TAPHONOMY SUBJECTS AND K/PG PALEOENVIRONMENTAL PROBES}

Ostracode carapaces are well suited for taphonomic investigations of the effects of acidification because they are composed of calcite and they exhibit a wide range of sizes, shapes, ornamentations, and thicknesses. Delicate ornamentation that is commonly used to distinguish among ostracode taxa may be particularly susceptible to dissolution damage. Ostracodes also are investigated here because of their potential usefulness in determining non-marine environmental conditions following the $\mathrm{K} / \mathrm{Pg}$ impact.

Although high-resolution biostratigraphic studies have documented changes in microfaunal diversity (planktonic foraminifera, nannoplankton, marine ostracodes, etc.) across impact horizons in marine settings (Smit, 1982; Keller, 1988; Coccioni and Galeotti, 1994; Pospichal, 1996; Arenillas et al., 2002), similar resolution in lacustrine settings has yet to be realized. Absent from the literature are descriptions of shelled limnetic invertebrates that reach or cross the $\mathrm{K} / \mathrm{Pg}$ boundary in sediments containing impact horizons. Such lacustrine records have proven difficult to obtain because of a limited number of identified terrestrial $\mathrm{K} / \mathrm{Pg}$ boundary sections that contain evidence of impact fallout. Additionally, lacustrine and riverine depositional settings generally provide laterally discontinuous sedimentary records.

A biostratigraphic record of microfossils (such as ostracodes) across terrestrial $\mathrm{K} / \mathrm{Pg}$ impact horizons would provide an opportunity to resolve the uncertainties surrounding impact-related extinctions in a lacustrine environment. Studies have demonstrated the utility of biostratigraphic records from marine ostracodes in illustrating the rate and severity of extinctions during the Late Devonian mass extinction event (e.g., Casier and Lethiers, 2002), and similar approaches could be employed in $\mathrm{K} / \mathrm{Pg}$ continental records. Ostracode assemblages have been described in the non-marine Upper Cretaceous and Lower Paleogene rocks of China (Ye, 1994; Chen, 1996) and northern Alaska (Brouwers and De Deckker, 1993), bracketing the K/Pg boundary. These studies are useful for understanding broad diversity patterns across the $\mathrm{K} / \mathrm{Pg}$ transition. However, because these localities lack evidence of geochemical or lithological indicators of the precise position of the $\mathrm{K} / \mathrm{Pg}$ boundary, their potential to illuminate the direct environmental and biotic effects of the Chicxulub impact is limited. Sediments containing shocked quartz, impact spherules, and an iridium anomaly record the geologically instantaneous Cretaceous-Paleogene impact event, and ostracodes have yet to be identified in sections that contain unambiguous impact horizons.

Before additional biostratigraphic studies of shelled limnetic organisms (such as ostracodes) are undertaken, it is important that the taphonomic processes associated with $\mathrm{K} / \mathrm{Pg}$ impact-generated acid precipitation are examined. Although these experiments focus specifically on ostracode preservation across the $\mathrm{K} / \mathrm{Pg}$ boundary, the results and the experimental approaches may be broadly applicable to preservation of ostracode carapaces and other types of calcareous shells under acidic burial conditions throughout geologic time.

\section{METHODS}

\section{Taphonomic Experiments}

Using known volumes and compositions of both sediment and water in experimental tanks, ostracode fossils were emplaced under simulated burial conditions. These simulated lake-bottom sediments then were subjected to variable acidification conditions. This experimental design was intended to provide a simulation of $\mathrm{pH}$ and buffering effects under the calm-water conditions that typify lake and pond bottoms where fine-grained sediments accumulate. These experiments do not address the complicating variables of strong wave and current activity present in large lakes. The results of the experiments were evaluated by removing the ostracodes from their burial positions at fixed time intervals, and then examining the taphonomic consequences of acidification.

Nine polystyrene tanks (Rolph C. Hagen Corp.), approximately 13 liters in volume, were filled with wet lake sediment to a depth of $12 \mathrm{~cm}$ to simulate small plots of the sediment-water interface from several hypothetical acidified paleolakes. The initial lake sediment used in the experimental tanks was obtained from surface sediments at the center of Rose Canyon Lake-a small reservoir in southern Arizona. The reservoir is situated in a high-elevation $(2134 \mathrm{~m})$, poorly buffered granitic catchment with high organic-matter input (primarily in the form of decaying plant and arthropod fragments) derived from a surrounding pine forest. The mean clast composition of the Rose Canyon Reservoir sand ( $>64 \mu \mathrm{m}$ fraction) consisted of $\sim 45 \%$ muscovite, $19 \%$ quartz, $6 \%$ hornblende, $9 \%$ feldspar, $16 \%$ plant/insect fragments, and $5 \%$ other rock fragments. Bulk sediments are primarily very fine-grained sand, with subordinate amounts of silt, clay, and coarsegrained sand, and trace amounts of gravel-sized arthropod and plant fragments. Loss-on-ignition analysis was used to determine an average organic carbon content of 3.78 wt\% (based on three replications) and an inorganic carbon concentration of $1.1 \mathrm{wt} \%$ (based on three replications) for the unmodified Rose Canyon sediment. This mud served as the unbuffered $\left(1 \% \mathrm{CaCO}_{3}\right)$ simulated lake sediment used in the experimental tanks. Initial manipulations of the inorganic carbon content of these tank sediments were used to simulate a range of initial lake alkalinity and bedrock-buffering conditions $\left(1 \%, 10 \%\right.$, and $\left.20 \% \mathrm{CaCO}_{3}\right)$. This was achieved using a calcium-carbonate powder (mean calcite particle size $=12 \mu \mathrm{m}$ ). The powder was stirred into the wet Rose Canyon sediment (approx. $1 \% \mathrm{CaCO}_{3}$ ) to obtain two additional homogeneous mixtures of sediment that contained $10 \mathrm{wt} \%$ and $20 \mathrm{wt} \% \mathrm{CaCO}_{3}$. These mixtures were used to approximate lacustrine marls with differing buffering capacities.

Because the Rose Canyon lake sediments were devoid of calcareous fossils, ostracode carapaces could be added at known depths below the sediment water interface (BSWI) in each tank to observe the interactions of acidified waters with sediments and carapaces. For this study, modern calcareous and shell-rich lake sediments from Lake Tanganyika, Africa were used as the experimentally emplaced 


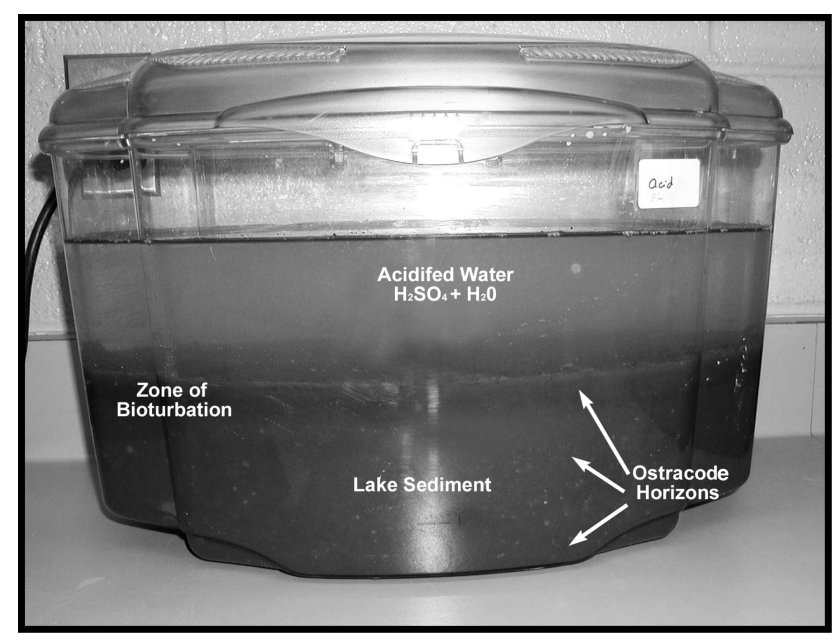

FIGURE 3-Experimental tank that simulates the sediment-water interface of acidified lakes. Ostracode carapaces were emplaced at horizons $1 \mathrm{~cm}, 5 \mathrm{~cm}$, and $10 \mathrm{~cm}$ below the sediment-water interface. The tank sediments also included a zone of bioturbation similar to the midge burrows found in many lake sediments.

material. These sediments were used because ostracode shells from this lake are distinctive, in a state of excellent (unworn) preservation, and cannot be confused with any rare local shell materials. Six grams of shelly medium- to coarse-grained quartz sand, containing approximately 200 ostracode valves, were emplaced in the tank sediment at depths of $1 \mathrm{~cm}, 5 \mathrm{~cm}$, and $10 \mathrm{~cm}$ BSWI (Fig. 3). Prior to emplacement, the fossiliferous material was mixed with 2 grams of inert colored sand in order to identify the emplacement horizon on recovery, and to evaluate the success of core recoveries.

Four liters of acidified water (reagent-grade sulfuric acid mixed with distilled water) were added to each tank to simulate acidic lake waters. These three sulfuric acid treatments ( $\mathrm{pH}$ 1.9, $\mathrm{pH} 3.0$, and $\mathrm{pH} 4.0$ ) were used in combination with each buffering treatment, with water changes every two days to maintain acidity and simulate input from runoff. Sulfuric acid was the only acid considered in these experiments, and was not mixed with nitric acid for safety reasons. The acidification treatments simulate the sulfuric-acid component of several possible post-Chicxulub acid-precipitation conditions derived from the effects of the impact event and the interaction of the acid with localized environmental conditions at the site of deposition.

In order to evaluate the preservation of the buried carapaces, four 10-cm-deep sediment cores were taken from each tank using a small (30-cm length, 2.5 -cm diameter) hand-operated piston corer. Cores were collected 3, 12, 42, and 150 days after the initial acidification in the four corners of each tank, to provide a logarithmically evenly spaced range of treatment intervals. Recovered cores were checked for the presence of a continuous horizon of colored sand to ensure complete core recovery. Five minutes of rinsing using deionized water followed by ten minutes of immersion in an ultrasonic cleaning bath was performed on the coring device to prevent cross-contamination between tanks.

Upon recovery, cored sediments were washed immediately with deionized water over a nested set of $125-\mu \mathrm{m}$ and $63-\mu \mathrm{m}$ sieves for five minutes and then air-dried. Cores were sampled at the $1-\mathrm{cm}, 5-\mathrm{cm}$, and $10-\mathrm{cm}$ burial-depth zones, recognized by the colored marker sands. To ensure maximal recovery, $1-\mathrm{cm}$ intervals above and below the marker sands also were included in the examined sediment fraction and counted along with that horizon. Each fraction that contained a recognizable carapace, even if damaged, was counted as a horizon with preserved carapaces. Each horizon was assigned to one of three categories (no carapaces preserved, 1 to 5 carapaces preserved, $>5$ carapaces preserved) by examining all of the cored sediment for each horizon using a binocular microscope. A chi-squared test was used to determine if associations existed between each variable and the degree of carapace preservation. If the chi-squared test resulted in a rejection of the null hypothesis, then no statistically significant association could be established between the experimental variable and carapace preservation. Core samples also were taken from untreated tank sediments (tanks filled with tap water $=\mathrm{pH}$ 7.7) to evaluate the coring device; test cores recovered an average of 33 ostracodes per stratigraphic interval.

Random ostracodes recovered from experimentally treated cores were stub-mounted using adhesive tape and coated with $300 \AA$ A of gold using a sputter coater. Dissolution damage to recovered ostracode carapaces was assessed using a Camscan II scanning electron microscope at a working distance of $11.5 \mathrm{~mm}$ and accelerating voltage of $15 \mathrm{keV}$.

\section{Field Sampling of K/Pg Boundary Sections}

The buffering potential of rocks that crop out within lake catchments during the $\mathrm{K} / \mathrm{Pg}$ event can be inferred loosely by examining the general composition of the underlying regional bedrock. While the experimental portion of this study simulated the effect that a number of possible environmental conditions may have had on the preservation of calcareous microfossils, the experimental conditions should be related to actual conditions via paleoenvironmental and paleogeological evidence (i.e., rocks exposed at the surface during the $\mathrm{K} / \mathrm{Pg}$ event). In order to make a preliminary assessment of fossil-preservation conditions for the purposes of comparing them to the experimental results, sampling for microfossils was conducted at two localities in Garfield County, Montana that expose palustrine/lacustrine sediments across the $\mathrm{K} / \mathrm{Pg}$ boundary. The Cretaceous Hell Creek Formation and the overlying Paleogene Fort Union Formation were deposited in a siliciclastic-floodplain environment cut by numerous meandering channels (Frye, 1969; Fastovsky and Dott, 1986; Fastovsky, 1987). Although rare, a few sedimentary sections, such as the Hauso Flat (N47 $31^{\prime} 41.4^{\prime \prime}$, W107 $10^{\prime} 32.3^{\prime \prime}$ ) and Smurphy's Guess (N47 $33^{\prime} 00.9^{\prime \prime}$, W106 $54^{\prime} 46.2^{\prime \prime}$ ) localities, contain laminated siltstones that probably were deposited in ponds or small lakes (Fastovsky, 1987; Arens, pers. comm., 2001). Impact evidence at the Hauso Flat locality is provided by an iridium anomaly of $11.7 \mathrm{ppb}$ (Smit and van der Kaars, 1984) and by the presence of shocked mineral grains (Swisher et al., 1993). The boundary claystone at the Hauso Flat locality occurs at the base of a 7- to 9-cm-thick lignite (Arens and Jahren, 2000). 


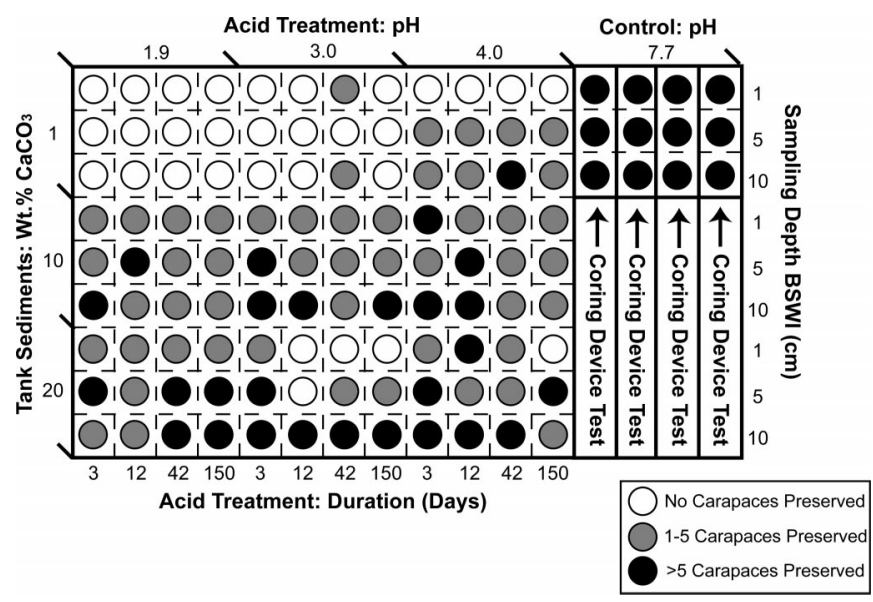

FIGURE 4-Experimental tank carapace preservation results. White indicates no carapace recovery from core. Gray indicates 1-5 carapaces preserved. Black indicates $>5$ carapaces preserved.

Small trenches, approximately $10-\mathrm{cm}$ deep, were dug into the outcrop at each locality to expose unweathered material. Twenty 1-kg sediment samples were collected at evenly spaced stratigraphic intervals of $20 \mathrm{~cm}$ in laminated gray mudstones and siltstones from $200 \mathrm{~cm}$ below to $200 \mathrm{~cm}$ above the boundary claystone at the Hauso Flat locality. An additional twenty samples were collected at 20$\mathrm{cm}$ intervals from Hell Creek Formation siltstones beneath the Z lignite at the Smurphy's Guess locality. Each sediment sample was split into two fractions. One fraction was subjected to freeze-thaw disaggregation. The other fraction was disaggregated by soaking in a solution of sodium hexametaphosphate $(\sim 5 \mathrm{~g}$ /liter $)$. Both fractions were sieved using distilled water over a set of $125-\mu \mathrm{m}$ and $63-$ $\mu \mathrm{m}$ screens and air-dried. Fine and coarse fractions from both methods of disaggregation were searched for microfossils and shell fragments using a binocular microscope.

\section{RESULTS}

\section{Tank Experiments}

The experiments presented here attempted to quantify the effects of the duration of acidification, burial depth, acid-buffering capacity, and groundwater $\mathrm{pH}$ on calcareous microfossil preservation. Figure 4 presents carapacerecovery data from cores of the experimental tank sediments. Table 2 presents chi-squared contingency tables for this data. The carapace-recovery results can be categorized by the treatment categories of burial depth, $\mathrm{pH}$ of tank water, acid-treatment duration, and carbonate buffering. Additional factors, unanticipated in the original experimental design but of importance for these results, such as bioturbation, also are considered here.

Depth: Ostracode carapace recovery varied systematically with burial depth (Fig. 5A). In total, 108 horizons were inspected for ostracodes. Thirty-one of these core horizons lacked carapaces. Of those horizons with no carapace recovery, fifteen were from the $1 \mathrm{~cm}$ below the sediment-water interface (BSWI), nine were from $5 \mathrm{~cm}$ BSWI, and seven were from $10 \mathrm{~cm}$ BSWI. The calculated $\chi^{2}$ value for burial depth was $16.839(\mathrm{df}=4)$ and a value for $p<$ 0.01 .
TABLE 2-Chi-square test contingency tables for water $\mathrm{pH}$, the duration of acid treatment, burial depth, and acid-buffering capacity. The tables test the null hypothesis that the experimental variable is independent of carapace recovery.

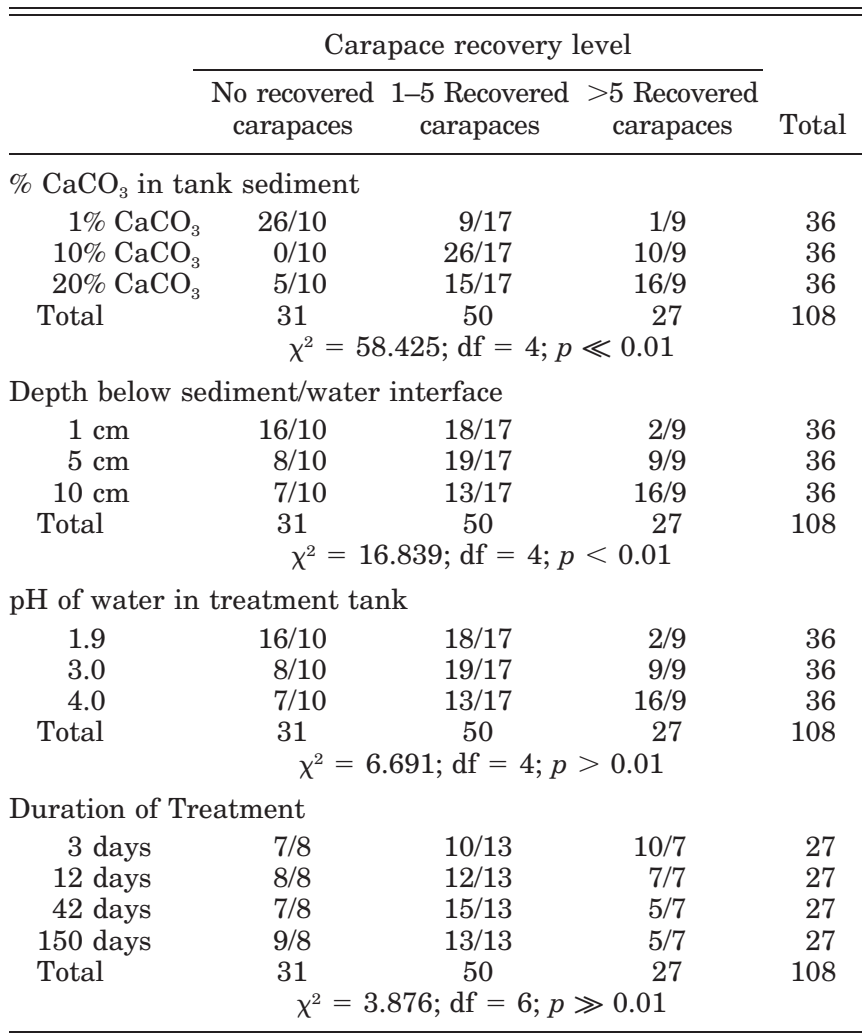

pH of Tank Water: Twelve of the 31 horizons with no carapace preservation came from the tanks subjected to $\mathrm{pH}$ 1.9 waters. Fourteen of the horizons came from $\mathrm{pH} 3.0$ tanks and only 4 from $\mathrm{pH} 4.0$ tanks (Fig. 5B). For pH, a $\chi^{2}$ value of $6.691(\mathrm{df}=4)$ was calculated and a value for $p \gg$ 0.01 .

Acid-Treatment Duration: Variability in carapace recovery appeared to correlate poorly with treatment duration (Fig. 5C). After three days of acid treatment, seven horizons were devoid of carapaces. After 12 days, the number of horizons without carapaces increased to nine. However, after 42 days, the number of horizons with no recovery decreased to six. This number indicates that in at least three cases, either preservation conditions or core recovery were not identical in laterally continuous horizons from the same experimental tank. After 150 days, the number of core horizons with no recovery (9) was the same as after 12 days. The calculated $\chi^{2}$ value for treatment duration was $3.876(\mathrm{df}=6)$ and a value for $p \gg 0.01$.

Carbonate Buffering: Of the 108 total recovered core sections, 31 contained no ostracode carapaces. Of these 31 core sections, $26(84 \%)$ were from tanks with the lowest $\left(1 \% \mathrm{CaCO}_{3}\right.$ ) buffering capacity (Fig. 5D). In the unbuffered $\left(1 \% \mathrm{CaCO}_{3}\right)$ tanks treated with $\mathrm{pH} 1.9$ water, none of the 12 core sections contained preserved ostracode carapaces. In the pH 3.0 unbuffered tanks, two of the 12 core sections contained carapaces, and in the $\mathrm{pH} 4.0$ unbuffered tanks, eight of the 12 core sections contained carapaces. The cal- 

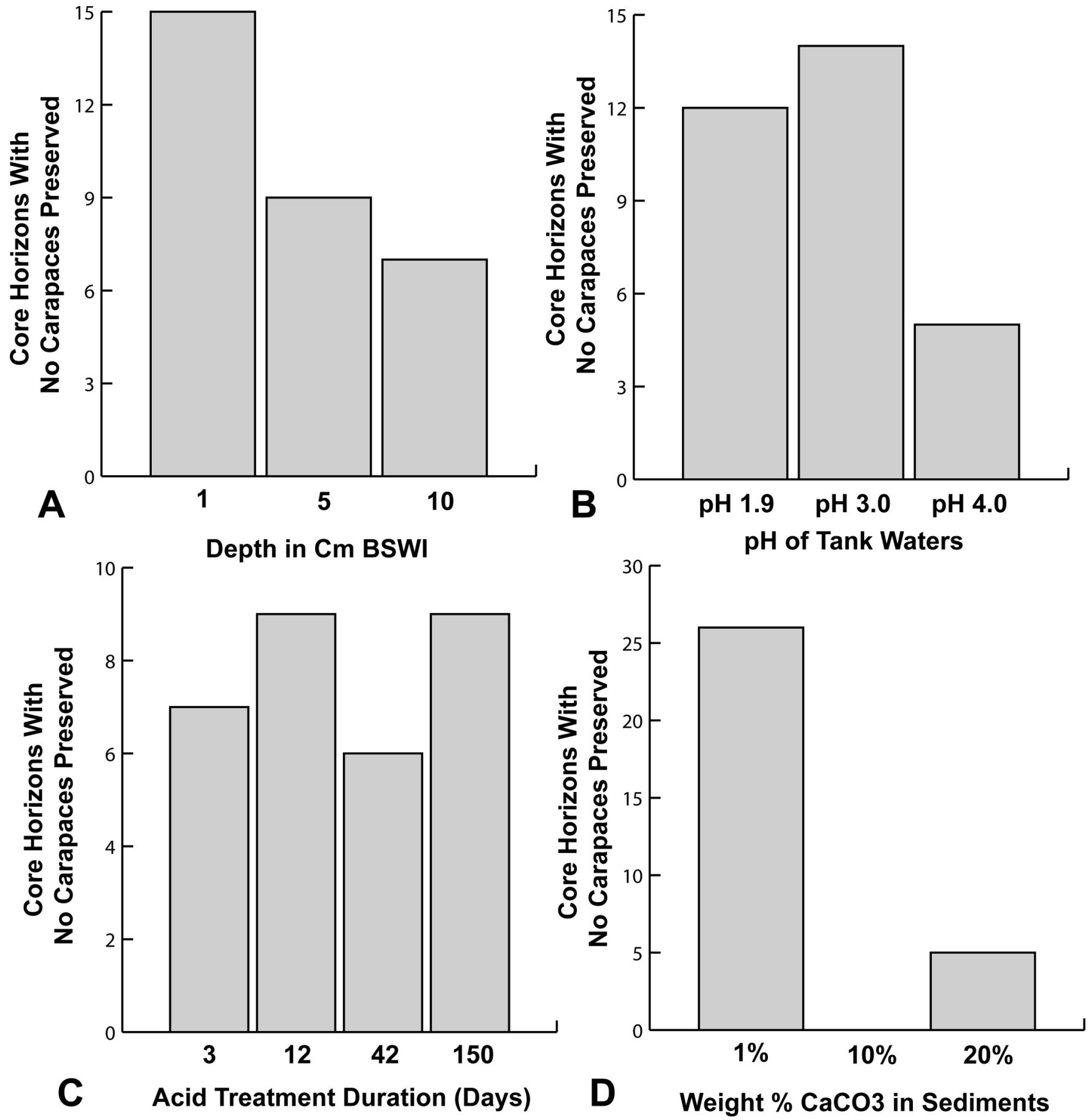

FIGURE 5-Relationship between experimental tank conditions and core horizons with no carapace preservation. (A) Effect of burial depth. (B) Effect of pH. (C) Effect of acid-treatment duration. (D) Effect of carbonate buffering.

culated $\chi^{2}$ value for carbonate buffering was $58.425(\mathrm{df}=$ $4)$ and a value for $p \ll 0.01$.

Bioturbation in Tank Sediments: The modern Rose Canyon lake sediments used in our experimental tanks all contained eggs of chironomids (unidentified lake midges of the dipteran family Chironomidae). The midge eggs were not placed intentionally in the tanks and were themselves, not part of the preservation experiment. The eggs hatched during initial setup and the burrowing action of the larvae created a zone of bioturbation. Figure 3 shows a zone of bioturbation that was present in all of the tank sediments. The mud in this zone contained abundant chironomid burrows ( $\sim 1 \mathrm{~mm}$ in diameter).

Over $90 \%$ of the burrows were limited to the top 1 to 3 $\mathrm{cm}$ BSWI, although some isolated burrows penetrated to depths of up to $8 \mathrm{~cm}$. After acidification of the tank waters, the larvae died in the following tanks: $\mathrm{pH}=1.9, \mathrm{CaCO}_{3}=$ $1 \% ; \mathrm{pH}=1.9, \mathrm{CaCO}_{3}=10 \%$; and $\mathrm{pH}=3, \mathrm{CaCO}_{3}=1 \%$. 


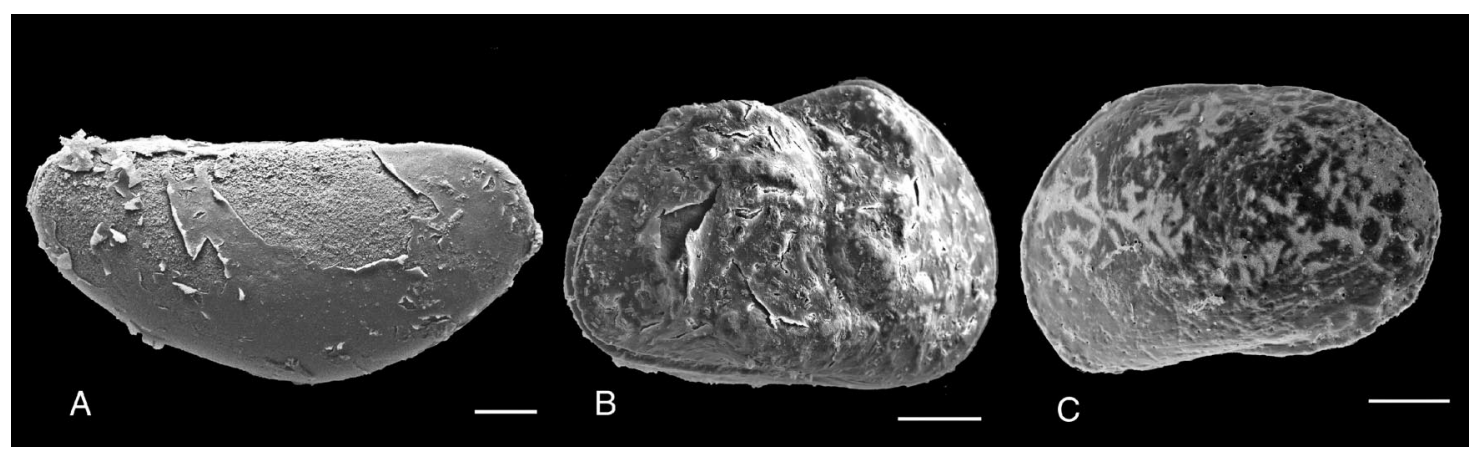

FIGURE 6-Ostracode specimens recovered from the experimental tank cores. White scale bar $=100 \mu \mathrm{m}$. (A) Lateral view of the right valve exterior of an ostracode carapace (Mecynocypria sp.) from a core taken in the experimental tank containing $\mathrm{pH}^{3.0} \mathrm{water}$ and $20 \% \mathrm{CaCO}_{3}$ in the tank sediment; carapace recovered from $10 \mathrm{~cm}$ BSWI. (B) Lateral view of the right valve exterior of an ostracode carapace (Mesocyprideis irsacae) from a core taken in the experimental tank containing $\mathrm{pH} 1.9$ water and $10 \% \mathrm{CaCO}_{3}$ in the tank sediment; carapace recovered from $5 \mathrm{~cm}$ BSWI. (C) Lateral view of the right valve exterior of an ostracode carapace (Gomphocythere lenis) from a core taken in the experimental tank containing pH 1.9 water and $20 \% \mathrm{CaCO}_{3}$ in the tank sediment; carapace recovered from $5 \mathrm{~cm} \mathrm{BSWI}$.

The chironomid larvae in the remaining tanks survived for the duration of the experiments and continued to produce zones of significant bioturbation within the top 1 to 3 $\mathrm{cm}$ of sediment in these tanks. Burrow densities and depths were similar in all experimental tanks except for the following two tanks: $\mathrm{pH}=1.9, \mathrm{CaCO}_{3}=1 \%$; and $\mathrm{pH}=$ $3, \mathrm{CaCO}_{3}=1 \%$, which had very low burrow densities.

Dissolution Damage to Recovered Carapaces: Because loss of information can result from partial fossil dissolution as well as complete dissolution, scanning electron microscopy was used to characterize dissolution damage to random samples from the recovered carapaces. A variety of species was examined to determine the qualitative effects of acid dissolution on different types of carapaces. Etching and dissolution pitting are exhibited in several specimens. The specimens in Figure 6A and 6B both exhibit a peeling appearance, which may be caused by acid dissolution of the outer layers of calcium carbonate, revealing micron-sized calcite crystals beneath. The specimen in Figure 6C contains etched areas (lighter) containing a rough crystalline texture different from the smooth areas of the unetched carapace. Several carapaces that appear partially dissolved also were broken.

\section{Field Sampling across the K/Pg Boundary}

Of the forty sediment samples from stratigraphic intervals collected across the impact claystone at the Hauso Flat and Smurphy's Guess localities, none contained calcareous shelly material. The laminated siltstones from above and below the boundary contained abundant siliceous-sponge spicules and fragments of aquatic plants similar to those described by Arens and Jahren (2000), which suggests that they were deposited in standing water. At the Smurphy's Guess locality, a shell-lag deposit in a sandstone facies was observed approximately $8 \mathrm{~m}$ below the sampled lignite. The shell bed contained several dozen unionid bivalves. Sediment from the shell lag was processed and analyzed for microfossils with negative results. Although siderite nodules commonly are observed in sandstone facies throughout the Hell Creek Formation, no nodules were observed in either of the siltstone-dominated sections subjacent to the boundary.

\section{DISCUSSION}

Tank Experiments

The results of the tank experiments demonstrate that the carbonate content of the host sediment was the most important factor in controlling the preservation of ostracode carapaces. Sedimentary grains have cation exchange sites on their surfaces (Munson and Gherini, 1991). When acidic water enters the sediment, hydrogen ions from the acidic solution are exchanged for base cations-in this case, the cations that were sorbed to the calcite in the sediments. This process produces alkalinity, and buffers the $\mathrm{pH}$ of the waters. In the absence of buffering by cations from sedimentary grains, acidic waters can dissolve calcareous shell material. Of the 31 horizons recovered from the experimental tanks that exhibited no preservation of carapaces, 26 (84\%) were from the sediments with the lowest buffering capacity $\left(1 \% \mathrm{CaCO}_{3}\right)$. The $p$ value for carbonate buffering was $\ll 0.01$, which indicates that this result is highly significant.

The importance of buffering appears somewhat independent of the acid severity at the lower $\mathrm{pH}$ values (1.9 and 3.0). Twelve of the 26 horizons (46\%) without preservation were from the tanks with the most-acidic $(\mathrm{pH} 1.9)$ waters. Ten horizons were from tanks with $\mathrm{pH} 3.0$ waters, and four were from those with $\mathrm{pH} 4.0$ waters. These experimental data suggest that different degrees of acidification would have had a negative impact on calcareous fossil preservation in unbuffered lakes, but that even moderately buffered calcareous sediments would have neutralized a range of local acid pore water conditions, allowing for preservation of buried calcareous fossils.

In the experimental tanks, the $\mathrm{pH}$ of water alone did not have a statistically significant effect $(p>0.01)$. The $\mathrm{pH}$ of $\mathrm{K} / \mathrm{Pg}$ acidified lakes would have varied widely, and as a result, the $\mathrm{pH}$ of experimental tank waters in these experiments simulated several values within a range of possible conditions. The total volume of inland rivers and lakes today is approximately $3.6 \times 10^{17}$ liters (Prinn and Fegley, 1987). If $5 \times 10^{15} \mathrm{~mol}$ of total acid equivalents fell on the continents, then, without any neutralization by buffering reactions, the acid concentration would have been $5 \times$ $10^{15} / 3.6 \times 10^{17}=0.014 \mathrm{~mol} /$ liter. This concentration is 
equivalent to a $\mathrm{pH}$ of approximately 1.9 - similar to the most-acidic treatment conditions in the experimental tanks. As discussed by Prinn and Fegley (1987), this type of dilution calculation assumes no geochemical interaction with the catchment. It represents a theoretical lower approximation for poorly buffered, low-alkalinity lakes using one estimate of acid deposition. The acid conditions in the pH 4.0 tank waters are similar to cases of severe acidification in modern lakes (e.g., Little Echo Pond, New York) subjected to anthropogenic acid precipitation, and the $\mathrm{pH}$ 3.0 conditions represent an arbitrary $\mathrm{pH}$ condition between the two other values.

In addition to the role of carbonate buffering, the depth of carapace burial also appears to have had a strong influence on preservation $(p<0.01)$. Fifteen of the 31 cores with no recovered carapaces were from a depth of $1 \mathrm{~cm}$ BSWI. These carapaces would have been the first subjected to diffusion of acidic water from above. In buffered sediments, the concentration of diffusing acid in pore waters will drop with depth as hydrogen ions are consumed by reaction with exchangeable cations in the sediment. The top 1 to $3 \mathrm{~cm}$ of the tank sediments were also the most heavily bioturbated. In the experimental tanks, chironomid burrows may have acted as conduits for acidic water and been important in dissolution of shallowly buried fossils in the less acidic tanks ( $\mathrm{pH} 4.0$ ). The irrigating influence of bioturbation appears to be far less significant than the buffering of the sediments, as evidenced by the observation that the two least-bioturbated and least-buffered tanks also had the lowest levels of carapace recovery. Despite the difficulties bioturbation imposed on standardizing diffusion properties between experimental tanks, it provided a more realistic model of burial conditions in actual lakes. Burrowing midge larvae are ubiquitous in modern lake sediments, forming the most important group of bioturbators in most lakes. By the Middle Cretaceous, chironomids had replaced the chaoborids (phantom midges) as the dominant dipteran inhabitants of eutrophic lakes (Blagoderov et al., 2002). Therefore, this type of effect most likely would have been a common occurrence in $\mathrm{K} / \mathrm{Pg}$ lake sediments exposed to acid precipitation. In real lakes, the effect of chironomid bioturbators would disappear beyond depths of 10 to $15 \mathrm{~cm}$, and depth likely would have a more significant effect on limiting dissolution of calcareous fossils below depths of a few tens of centimeters.

The recovery data from the experimental tanks suggest that the acid-treatment duration also may have influenced preservation, but to a lesser degree. The input of acid into a lake system can occur through direct atmospheric deposition as well as indirect deposition by runoff and groundwater transport. The durations of acid treatment used in the experiments represent several possible durations for acid precipitation and runoff. The cores taken after three days only had an initial acid input and could be used to approximate the effects of a single pulse of acidity. Regular replacement of the tank waters in the tanks cored at 12,42 , and 150 days was intended to simulate longer-duration acid inputs that could have occurred through direct precipitation into a lake or via runoff. Presumably, the applicability of either model to a particular $\mathrm{K} / \mathrm{Pg}$ lake would have depended upon the lake's particular hydrologic conditions and the timing of local acid precipitation.

In the experimental tanks, dissolution of all carapaces occurred in seven horizons after three days. Rapid diffusion of acidic waters through burrows below the sedimentwater interface may have allowed for the dissolution observed in the cores taken after three days of acid treatment. The number of horizons devoid of carapaces increased to nine after 12 days of treatment, and was still at nine horizons after 150 days of treatment. Because regular water changes were performed to maintain acid conditions in the tanks, this result suggests that reaction of fossiliferous material slowed or stopped following dissolution reactions early in the experiment. One possible explanation is that the initial acidification caused the formation of a reaction product such as a new mineral phase, which changed the porosity of the sediment or the reactivity potential of affected sediments. Another possibility is that some concentrations of carapaces were located near chironomid burrows and were dissolved during initial treatments, while others remained outside the reach of porewater diffusion for the duration of the experiment. Similar heterogeneities in diffusion properties of actual lake sediments may result from variations in lithology, bioturbation, and diagenetic alteration.

The SEM images presented here (Fig. 6A-C) show dissolution damage to some carapaces. Damage from acidic conditions can cause loss of information if surface ornamentation (used for identification of many fossil and modern species) is subdued or removed by dissolution. In addition, dissolution effects are likely to cause weakening of delicate carapaces, increasing the likelihood of physical breakage during diagenesis, collection, and sample preparation. Although the damage shown is likely the result of acid treatments, the possibilities of microbial damage formed in the experimental tanks or preexisting taphonomic damage cannot be discounted entirely. Shell mineralogy composition and crystal shape, size, and arrangement all can affect the dissolution properties of skeletal carbonates (Henrich and Wefer, 1986). The importance of these factors in the dissolution of large benthic foraminifera is summarized by Beavington-Penney (2004). Microarchitecture of calcareous microfossils may determine the dissolution resistance and texture exhibited in some damaged specimens, as originally suggested by Swanson and van der Lingen $(1994,1997)$, although no easily explained correlations between texture and structure were observed in this study.

\section{Implications for Interpreting Fossil-Preservation Conditions at the $\mathrm{K} / \mathrm{Pg}$ Boundary}

The complexity of chemical and hydrological interactions that occur during lake acidification makes the use of sophisticated numerical models a requirement for predicting $\mathrm{pH}$ based on acid input. Lake-acidification numerical models, such as ILWAS, ETD, and MAGIC (Chen et al., 1984; Cosby et al., 1985; Nikolaidis et al., 1989), may be useful in calculating the effects of the Chicxulub acid trauma on various types of hypothetical Cretaceous lakes. In the absence of quantitative estimates of the acidification, for purposes of interpreting the fossil-preservation potential of a sedimentary environment, a general assessment of the buffering conditions in the local catchment and lake sediments can be estimated using observations of local lithology. Such an assessment of the burial conditions and 
TABLE 3-Geological and paleoenvironmental factors that may have influenced acid-neutralizing potential at known K/Pg boundary localities. References: Nichols, 1990; Orth et al., 1981; Pillmore et al., 1984; Pillmore and Flores, 1987; Sweet and Braman, 1992 ; Vajda et al., 2001.

\begin{tabular}{|c|c|c|c|}
\hline Location & Lithology & $\begin{array}{l}\text { Paleoenvironmental } \\
\text { conditions }\end{array}$ & Acid-Buffering potential \\
\hline $\begin{array}{l}\text { Raton Formation, Raton Basin, } \\
\text { Colorado and New Mexico }\end{array}$ & $\begin{array}{l}\text { A } 300-700-m-\text { thick sequence of } \\
\text { sandstone, siltstone, coal, } \\
\text { carbonaceous shale, and con- } \\
\text { glomerate. }\end{array}$ & $\begin{array}{l}\text { Channel-dominated floodplain } \\
\text { and swamps. High organic- } \\
\text { acid production from plants. }\end{array}$ & $\begin{array}{l}\text { Poor (similar to the poorly } \\
\text { buffered experimental } \\
\text { tanks). }\end{array}$ \\
\hline $\begin{array}{l}\text { Alberta and Saskatchewan, } \\
\text { Western Canada }\end{array}$ & $\begin{array}{l}\text { Mudstones with extensive coal } \\
\text { horizons. Some laterally dis- } \\
\text { continuous calcareous soils. }\end{array}$ & $\begin{array}{l}\text { Floodplain with rising water } \\
\text { table and transition to boggy } \\
\text { conditions. }\end{array}$ & $\begin{array}{l}\text { Poor overall. Very poor in } \\
\text { bogs, possibly moderate in } \\
\text { vicinity of calcareous soils. }\end{array}$ \\
\hline $\begin{array}{l}\text { Hell Creek Formation, Willis- } \\
\text { ton Basin, Montana and } \\
\text { North Dakota }\end{array}$ & $\begin{array}{l}\text { Sandstone, siltstone, mud- } \\
\text { stone, lignite horizons. }\end{array}$ & $\begin{array}{l}\text { Channel-dominated and mod- } \\
\text { erately well-drained flood- } \\
\text { plain with isolated palu- } \\
\text { strine environments. }\end{array}$ & $\begin{array}{l}\text { Poor (similar to the poorly } \\
\text { buffered experimental } \\
\text { tanks). }\end{array}$ \\
\hline $\begin{array}{l}\text { Moody Creek Mine Section, } \\
\text { West Coast, New Zealand }\end{array}$ & Mudstones with coal horizons. & $\begin{array}{l}\text { Palustrine (swampy) condi- } \\
\text { tions. }\end{array}$ & $\begin{array}{l}\text { Poor (similar to the poorly } \\
\text { buffered experimental } \\
\text { tanks). }\end{array}$ \\
\hline
\end{tabular}

regional geology can be related to a particular set or range of experimental taphonomy conditions and the corresponding fossil-preservation data presented here.

Paleoenvironmental conditions derived from the sedimentary and palynological record of $\mathrm{K} / \mathrm{Pg}$ boundary impact-fallout localities provide a framework for studying the acid-buffering capacity and fossil-preservation potential of calcareous material buried in these environments. All of the currently identified K/Pg impact horizons from continental aquatic settings were deposited in poorly buffered environments (Table 3 ). The preservation conditions for these environments are likely to be approximated most closely using data from the experimental tanks with $1 \%$ $\mathrm{CaCO}_{3}$ content. The $\mathrm{pH}$ of local waters would have depended largely on the duration and severity of the event because acidic runoff would have been little affected by rocks and sediments in the catchment. If correct, this inference suggests that calcareous fossil preservation at known K/Pg boundary localities was poor, and calcareous material may have been dissolved by acid rain. Field samples in this study from $2 \mathrm{~m}$ below to $2 \mathrm{~m}$ above the Hell Creek-Tullock Formation lack calcareous material, despite the presence of calcareous shells within 10 meters of the boundary.

While it is possible that ostracodes simply were not present in environments represented by the Hell Creek Formation, the absence of all calcareous material in standingwater deposits near the boundary suggests poor fossilpreservation conditions. Indeed, the excellent preservation of snails and bivalves deeper in the Hell Creek Formation strata, followed by an interval of apparent disappearance of many taxa near the boundary, is consistent with a change in fossil-preservation conditions in the uppermost Cretaceous sediments. For example, freshwater snails occur approximately 1.7 meters above the $\mathrm{K} / \mathrm{Pg}$ boundary in lowermost Paleocene rocks of the Fort Union Formation and freshwater bivalves disappear 1 to 2 meters below the boundary in Uppermost Cretaceous rocks of the Hell Creek Formation in eastern Montana (Hartman, 1998), but neither is found in close proximity $(<1 \mathrm{~m})$ to the boundary itself. Mollusk-shell impressions and steinkerns are present within 1 meter of the K/Pg boundary in North Dakota, but the shells themselves are not preserved
(Hartman et al., 2001), which also suggests that these organisms were present, but that conditions were not favorable for the preservation of calcareous material. However, the close association of Hell Creek sediments containing aquatic-plant fragments with the observed absence of preserved calcareous material in $\mathrm{K} / \mathrm{Pg}$ boundary sediments serves to underscore the difficulty in distinguishing fossil dissolution by impact-generated acid waters from dissolution that results from organic-acid-rich soils in humid environments. Because the absence of calcareous material extends for several meters above the $\mathrm{K} / \mathrm{Pg}$ boundary, it is unlikely that the lack of fossils in the upper meters of the Hell Creek Formation is due solely to leaching by impactgenerated acid rain. One explanation is that acid leaching destroyed shelly material beneath the boundary, while the disruption of ecosystems and extinctions caused by the impact event is responsible for the fossil-depauperate condition of the lower Paleogene sediments. Another plausible explanation is that swampy vegetation on the coastal floodplain followed the retreating Western Interior Seaway. Organic acids released by plants such as Sphagnum (Clymo, 1984) and decaying plant material may have created acidic soils and poor carbonate-fossil preservation conditions in this environment.

Testing the acid-leaching hypothesis is complicated further by the necessity of distinguishing between last appearances of taxa due to acid leaching and last appearances caused by actual extinctions or changes in ecology or biogeography. For example, freshwater bivalves are abundant in the upper Hell Creek Formation. Twelve species of bivalve are present within 6 meters of the $\mathrm{K} / \mathrm{Pg}$ boundary, however bivalves disappear within 1 to 2 meters of the Hell Creek-Tullock formational contact (Hartman and Butler, 1995; Hartman, 1996; Hartman, 1998). Hartman (1998) concluded that patterns of last appearances for freshwater bivalves in the uppermost Cretaceous sediments of the Hell Creek Formation are not consistent with extinction by bolide impact, and are instead due to habitat changes brought about by the retreating Cannonball Sea. This interpretation certainly could be correct. However, a change in fossil-preservation conditions, resulting from organic acids or impact-generated acid rain, potentially could blur biostratigraphic records of the abrupt faunal 
transitions often associated with sudden catastrophic mass extinctions.

The acidic conditions found in lakes with poorly buffered catchment bedrock and sediments, which allow for the dissolution of fossils, also could lead to acid-related extinctions. Prinn and Fegley (1987) proposed that lake systems buffered by carbonate rocks might have acted as refuges for some lacustrine organisms. Prinn and Fegley (1987) and Retallack (1996) also proposed that acid buffering by calcareous soils could have been responsible for the low extinction levels observed in amphibians and other aquatic organisms (Archibald and Bryant, 1990). Elimination of an entire species from its range in an area of acid-sensitive lakes is a likely consequence of global and extremely rapid acidification, whereas the congeners of this species inhabiting a region that includes well-buffered lakes might have survived the $\mathrm{K} / \mathrm{Pg}$ acid trauma with little difficulty. This may explain the apparent survival of most freshwater higher taxa (genera/families) across the $\mathrm{K} / \mathrm{Pg}$ boundary, but the simultaneous extinction of many species (e.g., Archibald and Bryant, 1990; Jablonski, 1991). The experimental data presented here suggest that the same acid-buffering conditions that would have been conducive to species survival also would have favored the preservation of carbonate material. Similarly, calcareous invertebrates in poorly buffered habitats, by analogy with modern ecosystems, would be more susceptible to ecosystem stress and poor preservation of their shells. In order for researchers to obtain an accurate biostratigraphic record of sudden $\mathrm{K} / \mathrm{Pg}$ acid-induced extinction, acidification of a particular depositional environment would have had to have been severe enough to cause biological damage, but not simultaneous leaching of buried calcareous remains.

\section{CONCLUSIONS}

These data suggest that buffering capacity, rather than $\mathrm{pH}$, time, or burial depth, is the primary mitigating factor for microfossil preservation in acid-stressed lacustrine environments. Because buffering capacity is governed by the mineralogical composition of the bedrock, calcareous-fossil preservation in lacustrine deposits just below the $\mathrm{K} / \mathrm{Pg}$ boundary can be assessed to determine if there is a correlation with Late Cretaceous paleogeology. Field data from the Hell Creek Formation presented here are consistent with the hypothesis that the disappearance of calcareous shells immediately beneath the boundary could have resulted from acidic burial conditions, although not exclusively those brought about by impact-generated acid rain. The absence of calcareous fossils also could be due to sampling bias, or biological absence, and cannot be used as direct evidence of acidic conditions.

The experimental data reported here suggest that taphonomic bias due to shell dissolution is far less likely in well-buffered environments than in poorly buffered settings. Under acidic conditions, preservation potential of calcareous lacustrine fossils would have been much higher when buried in well-buffered sediments in lakes whose catchments contain limestone outcrops and/or calcareous sediments. Preservation potential would have been poor to nonexistent in the records of lakes underlain by granitic or metamorphic rocks, where shelly material is buried in sil- iciclastic sediments. Efforts to locate calcareous microfossils across currently identified $\mathrm{K} / \mathrm{Pg}$ boundary palustrine and lacustrine sections are unlikely to be successful, given that floodplains with high levels of organic acids dominate the paleoenvironments of the few identified terrestrial K/ Pg boundary localities in North America and New Zealand. Thus, future attempts to document extinction patterns of lacustrine organisms across the $\mathrm{K} / \mathrm{Pg}$ boundary will require identification of paleolake deposits from wellbuffered catchments. The invertebrate record in moderately buffered settings may be instructive in determining the duration of acidification (and other environmental effects from the impact) and time to recolonization of previously acidified habitats. In well-buffered lacustrine environments across the $\mathrm{K} / \mathrm{Pg}$ boundary, it is predicted that calcareous fossil preservation will be good, and extinctions of ostracodes and other organisms, if they occurred at all, would have been caused by factors other than impact-generated acidification.

Understanding the heterogeneity of acid-rain effects on both inland paleohabitats and fossil-preservation conditions is important to interpreting $\mathrm{K} / \mathrm{Pg}$ extinction patterns. These results suggest that biostratigraphic studies of fossils studied from K/Pg-boundary, shallow-water sediments should be viewed within the context of local acidbuffering conditions.

\section{ACKNOWLEDGEMENTS}

This study was funded by a student research grant from the University of Arizona Department of Geosciences, a grant from the Western Alliance for Expanding Student Opportunities (WAESO), and a subcontract from the University of Washington to the University of Arizona as part of the NASA Astrobiology Program. We thank Nan Arens for guidance in the field, Rebecca Gomez Bailey and Jim Morrison for lab assistance, in addition to David Goodwin, Tina Schuster, Kay Behrensmeyer, Beverly Flood, and Karl Flessa for helpful discussions. JVB thanks Frank Corsetti for his thoughtful comments on earlier versions of this manuscript. We also thank PALAIOS reviewers David Finkelstein, Lisa Park, Michael Schudack, and one anonymous reviewer who provided constructive, thorough, and insightful reviews of this manuscript.

\section{REFERENCES}

Alvarez, L.W., Alvarez, W., Asaro, F., and Michel, H.V., 1980, Extraterrestrial cause for the Cretaceous-Tertiary extinction: Science, v. 208, p. 1095-1108.

ARCHIBALD, J.D., and BRYANT, L.J., 1990, Differential Cretaceous/ Tertiary extinctions of nonmarine vertebrates: evidence from northeastern Montana: in Sharpton, V.L., and Ward, P.D., eds., Global Catastrophes in Earth History: An Interdisciplinary Conference on Impacts, Volcanism, and Mass Mortality: Geological Society of America Special Paper 247, p. 549-562.

Arenillas, I., Alegret, L., Arz, J.A., Liesa, C., Meléndez, A., MoLiNA, E., Soria, A.R., Cedillo-Pardo, E., Grajales-Nishimura, J.M., and Rosales-Domínguez, C., 2002, Cretaceous-Tertiary boundary planktic foraminiferal mass extinction and biochronology at La Ceiba and Bochil, Mexico, and El Kef, Tunisia: in Koeberl, C., and MacLeod, K.G., eds., Catastrophic Events and Mass Extinctions: Impacts and Beyond: Geological Society of America Special Paper 356, p. 253-264.

ARENS, N.C., and JAHREN, H.A., 2000, Carbon isotope excursion in at- 
mospheric $\mathrm{CO}_{2}$ at the Cretaceous-Tertiary boundary: evidence from terrestrial sediments: PALAIOS, v. 15, p. 314-322.

ARGYLE, E., 1989, The global fallout signature of the K/T bolide impact: Icarus, v. 77 , p. 220-222.

BAKER, J.P., and SCHOFIELD, C.L., 1982, Aluminum toxicity to fish in acidic waters: Water, Air, and Soil Pollution, v. 18, p. 289-309.

BATTARBEE, R.W., 1984, Diatom analysis and the acidification of lakes: Philosophical Transactions of the Royal Society of London, Biological Sciences, v. 305, p. 451-477.

Battarbee, R.W., Allott, T.E.H., Juggins, S., Kreiser, A.M., CuRTIS, C., and HARRIMAN, R., 1996, Critical loads of acidity to surface waters: an empirical diatom-based palaeolimnological model: Ambio, v. 25, p. 366-369.

BEAMISH, R.J., 1976, Acidification of lakes in Canada by acid precipitation and the resulting effects on fishes: Water, Air, and Soil Pollution, v. 6, p. 501-514.

BeAvington-PenNey, S.J., 2004, Analysis of the effects of abrasion on the test of Palaeonummulites venosus: implications for the origin of nummulithoclastic sediments: PALAIOS, v. 19, p. 143-155.

Blagoderov, V.A., LuKASHEvich, E.D., and Mostovski, M.B., 2002, Order Diptera: in Rasnitsyn, A.P., and Quicke, D.L.J., eds., History of Insects: Kluwer Academic Publishers, Dordrecht, p. 227240.

BLUTH, G.J.S., and KUMP, L.R., 1994, Lithologic and climatologic controls on river chemistry: Geochimica et Cosmochimica Acta, v. 58 , p. 2341-2359.

BoHOR, B.F., FoORD, E.E., Modreski, P.J., and TrIPLEHORN, D.M., 1984, Mineralogic evidence for an impact event at the CretaceousTertiary boundary: Science, v. 224, p. 867-869.

BRAKKE, D.F., and LORANGER, T.J., 1986, Acid neutralizing capacity of lakes in the North Cascades area of Washington State: Water, Air and Soil Pollution, v. 30, p. 1045-1053.

BRETT, R., 1992, The Cretaceous-Tertiary extinction: a lethal mechanism involving anhydrite target rocks: Geochimica et Cosmochimica Acta, v. 56, p. 3603-3606.

BRouwers, E.M., and DECKKER, P.D., 1993, Late Maastrichtian and Danian ostracode faunas from northern Alaska: reconstructions of environment and paleogeography: PALAIOS, v. 8, p. 140-153.

CASIER, J.G., and LETHIERS, F., 2002, Ostracodes prove that the Frasnian/Famennian boundary mass extinction was a major and abrupt crisis: in Buffetaut, E., and Koeberl, C., eds., Geological and Biological Effects of Impact Events, v. 1: Springer-Verlag, Heidelberg, p. 1-10.

CHARLES, D.F., 1985, Relationships between surface water sediment diatom assemblages and lakewater characteristics in Adirondack lakes: Ecology, v. 66, p. 994-1011.

Chen, C.W., GHERINI, S.A., DEAn, J.D., Hudson, R.J.M., and GolDSTEIN, R.A., 1984, Development and calibration of the integrated lake-watershed acidification study model: in Schnoor, J.L., ed., Modeling of Total Acid Precipitation Impacts; Ann Arbor Science, Butterworth Publishers, Boston, p. 175-203.

CHEN, P.J., 1996, Freshwater biota, stratigraphic correlation of Late Cretaceous of China: in Sahni, A., ed., Cretaceous Stratigraphy and Paleoenvironments, Memoirs of the Geological Society of India 37 , p. 35-62.

ClaybuRN, J.K., SMith, D.L., and HaYward, J.L., 2004, Taphonomic effects of $\mathrm{pH}$ and temperature on extant avian dinosaur eggshell: PALAIOS, v. 19, p. 170-177.

Clymo, R.S., 1984, Sphagnum-dominated peat bog: a naturally acid ecosystem: Philosophical Transactions of the Royal Society of London Series B, v. 305, p. 487-499.

Coccioni, R., and GALEOTTI, S., 1994, K/T boundary extinction: geologically instantaneous or gradual event? Evidence from deep-sea benthic foraminifera: Geology, v. 22, p. 779-782.

Cosby, B.J., HoRnBERGER, G.M., GALlOWAY, J.N., and Wright, R.F., 1985, Modeling the effects of acid deposition: assessment of a lumped parameter model of soil water and streamwater chemistry: Water Resources Research, v. 21, p. 51-63.

CRUTZEN, P.J., 1987, Acid rain at the K/T boundary: Nature, v. 330, p. 108-109.

D'Hondt, S., Pilson, M.E.Q., Sigurdssson, H., and Carey, S., 1994, Surface-water acidification and extinction at the Cretaceous-Tertiary boundary: Geology, v. 22, p. 983-986.
Driscoll, C.T., Lawrence, G.B., Bulger, A.J., Butler, T.J., Cronan, C.S., EAGAR, C., LAMBERT, K.F., Likens, G.E., STODDARD, J.L., and WeAtHers, K.C., 2001, Acidic deposition in the northeastern U.S.: sources and inputs, ecosystems effects, and management strategies: BioScience, v. 51, p. 180-198.

Eilers, J.M., BrakKe, D.F., LANDERs, D.H., and Linthurst, R.A., 1987, Factors contributing to differences in acid neutralizing capacity among lakes in the western United States: in Dworsky, R.F., ed., Water Resources Related to Mining and Energy: American Water Resources Association, Bethesda, p. 403-418.

EILERS, J.M., and SELLE, A.R., 1991, Geographic overview of the regional case study areas: in Charles, D.F., ed., Acidic Deposition and Aquatic Ecosystems: Springer-Verlag, New York, p. 107-125.

FASTOVsKY, D.E., 1987, Paleoenvironments of vertebrate-bearing strata during the Cretaceous-Paleocene transition, eastern Montana and western North Dakota: PALAIOS, v. 2, p. 282-295.

FASTOVSKY, D.E., and DotT, R.H., JR., 1986, Sedimentology, stratigraphy, and extinctions during the Cretaceous-Paleogene transition at Bug Creek, Montana: Geology, v. 14, p. 279-282.

FREDA, J., 1986, The influence of acidic pond water on amphibians: a review: Water, Air, and Soil Pollution, v. 30, p. 439-450.

FRYE, C.I., 1969, Stratigraphy of the Hell Creek Formation in North Dakota: North Dakota Geological Survey Bulletin, No. 54, 65 p.

GoLDICH, S.S., 1938, A study in rock weathering: Journal of Geology, v. 46, p. $17-58$.

GuPTA, S.C., AHREns, T.J., and YANG, W., 2001, Shock-induced vaporization of anhydrite and global cooling from the $\mathrm{K} / \mathrm{T}$ impact: Earth and Planetary Science Letters, v. 188, p. 399-412.

HARTMAN, J.H., 1996, Extinction of sculptured nonmarine bivalves about the Cretaceous-Tertiary boundary: in Wolberg, D.L., and Stump, E., eds., Programs and Abstracts: DinoFest II International Symposium, Tempe, p. 58.

HARTMAN, J.H., 1998, The biostratigraphy and paleontology of Latest Cretaceous and Paleocene freshwater bivalves from the Western Williston Basin, Montana, U.S.A.: in Johnston, P.A., and Haggart, J.W., eds., International Symposium on the Paleobiology and Evolution of the Bivalvia, Drumheller (Bivalves: An Eon of Evolution-Paleobiological Studies Honoring Norman D. Newell): University of Calgary Press, Calgary, p. 317-345.

HARTMAN, J.H., and ButLER, R.D., 1995, Extinction and recovery of nonmarine molluscan assemblages in the Late Cretaceous and early Tertiary: Geological Society of America Abstracts with Programs, v. 27,6, p. 13.

HARTMAN, J.H., JOHNSON, K.R., and Nichols, D.J., 2001, The last freshwater molluscan assemblage of the Cretaceous? A new locality from the Ludlow Formation of North Dakota: Proceedings of the North Dakota Academy of Science, v. 55, p. 63.

Hartmann, H., and SteinberG, C., 1986, Mallomonadacean (Chrysophyceae) scales; early biotic paleoindicators of lake acidification: Hydrobiologia, v. 143, p. 87-91.

HENRICH, R., and WeFER, G., 1986, Dissolution of biogenic carbonates: effects of skeletal structure: Marine Geology, v. 71, p. 341362.

Hildebrand, A.R., Penfield, G.T., Kring, D.A., Pilkington, D., CAMARGO, A., JACOBSEN, S.B., and BoynTON, W.V., 1991, Chicxulub Crater: a possible Cretaceous-Tertiary boundary impact crater on the Yucatan peninsula: Geology, v. 19, p. 867-871.

Ivanov, B.A., BADUKOv, D.D., YAKOVLEv, O.I., Gerasimov, M.V., DIKOV, Y.P., POPE, K.O., and OCAMPO, A.C., 1996, Degassing of sedimentary rocks due to Chicxulub impact: hydrocode and physical simulations: in Ryder, G., Fastovsky, D., and Gartner, S., eds., The Cretaceous-Tertiary Event and Other Catastrophes in Earth History: Geological Society of America Special Paper 307, p. 125139.

JABLONSKI, D., 1991, Extinctions: a paleontological perspective: Science, v. 253 , p. 754-756.

KELLER, G., 1988, Extinction, survivorship and evolution of planktic foraminifera across the Cretaceous/Tertiary boundary at El Kef, Tunisia: Marine Micropaleontology, v. 13, p. 239-263.

KRING, D.A., 1993, The Chicxulub impact event and possible causes of K/T boundary extinctions: in Boaz, D., and Dornan, M., eds., Proceedings of the First Annual Symposium of Fossils of Arizona: 
Mesa Southwest Museum and Southwest Paleontological Society, Mesa, p. 63-79.

KRING, D.A, 1995, The dimensions of the Chicxulub impact crater and impact melt sheet: Journal of Geophysical Research, v. 100, p. $16,979-16,986$.

KRING, D.A., 2000, Impact events and their effect on the origin, evolution, and distribution of life: GSA Today, v. 10, p. 1-7.

KRING, D.A., 2003, Environmental consequences of impact cratering events as a function of ambient conditions on Earth: Astrobiology, v. 3, p. 133-152.

KRING, D.A., and DuRDA, D.D., 2002, Trajectories and distribution of material ejected from the Chicxulub impact crater: implications for post impact wildfires: Journal Geophysical Research, v. 107, p. 6-22.

KRING, D.A., Hildebrand, A.R., and Boynton, W.V., 1991, The petrology of an andesitic melt rock and a polymict breccia from the interior of the Chicxulub Structure, Yucatan, Mexico: Abstracts of the Lunar and Planetary Science Conference, v. 22, p. 755.

Kring, D.A., Melosh, H.J., and Hunten, D.M., 1996, Impact-induced perturbations of atmospheric sulfur: Earth and Planetary Science Letters, v. 140, p. 201-212.

Lajewsi, C.K., Mullins, H.T., Patterson, W.P., and Callinan, C.W., 2003, Historic calcite record from the Finger Lakes, New York: impact of acid rain on a buffered terrane: Geological Society of America Bulletin, v. 115, p. 373-384.

Lewis, J.S., Watkins, G.H., HaRtman, H., and PrinN, R.G., 1982, Chemical consequences of major impact events on earth: in Silver, L.T., and Schultz, P.H., eds., Geological Implications of Impacts of Large Asteroids and Comets on the Earth: Geological Society of America Special Paper 190, p. 215-221.

Likens, G.E., Bormann, F.H., and Johnson, N.M., 1972, Acid rain: Environment, v. 14, p. 33-40.

Linse, A.R., 1992, Is bone safe in a shell midden?: in Stein, J.K., ed., Deciphering a Shell Midden: Academic Press, California, p. 327347.

MacDougall, J.D., 1988, Seawater strontium isotopes, acid rain, and the Cretaceous-Tertiary boundary: Science, v. 239, p. 485487.

MacLeod, K.G., Huber, B.T., and Fullagar, P.D., 2001, Evidence for a small $(\sim 0.000030)$ but resolvable increase in seawater ${ }^{87} \mathrm{Sr} /$ ${ }^{86} \mathrm{Sr}$ across the Cretaceous-Tertiary boundary: Geology, v. 29, p. 303-306.

MARUOKA, T., and KoeBerL, C., 2003, Acid-neutralizing scenario after the Cretaceous-Tertiary impact event: Geology, v. 31, p. 489492.

Maruoka, T., Koeberl, C., Newton, J., Gilmour, I., and Bohor, B.F., 2002, Sulfur isotopic compositions across terrestrial Cretaceous-Tertiary boundary successions: in Koeberl, C., and MacLeod, K., eds., Catastrophic Events and Mass Extinctions: Impacts and Beyond: Geological Society of America Special Paper 356, p. 337-344.

McArthur, J.M., Thirlwall, M.F., EngKilde, M., Zinsmeister, W.J., and HowARTH, R.J., 1998, Strontium isotope profiles across $\mathrm{K} / \mathrm{T}$ boundary sequences in Denmark and Antarctica: Earth and Planetary Science Letters, v. 160, p. 179-192.

Melosh, H.J., Schneider, N.M., ZAhNle, K.J., and Latham, D., 1990, Ignition of global wildfires at the K/T boundary: Nature, v. 343 , p. 251-254.

Morgan, J., Warner, M., Brittan, J., Buffler, R., Camargo, A., Christenson, G., Denton, P., Hildebrand, A.R., Hobs, R., MaCintrye, H., Mackenzie, G., Maguire, P., Marín, L., Nakamura, Y., Pilkington, M., Sharpton, V.L., SNyder, D., SuÁrez, G., and TREJO, A., 1997, Size and morphology of the Chicxulub impact crater: Nature, v. 390 , p. $472-476$.

Muniz, I.P., LeIvestad, H., and Rosseland, B.O., 1978, Measurements of stress on fish in acidified rivers: methods and some results: Nordforsk Publication, v. 2, p. 233-247.

Munson, R.K., and GHERINI, S.A., 1991, Hydrochemical assessment methods for analyzing the effects of acidic deposition on surface waters: in Charles, D.F., ed., Acidic Deposition and Aquatic Ecosystems: Regional Case Studies: Springer-Verlag, New York, p. 35-64.

NicHOLs, D.J., 1990, Geologic and biostratigraphic framework of the non-marine Cretaceous-Paleogene boundary interval in western North America: Review of Palaeobotany and Palynology, v. 66, p. $75-84$.

Nikolaidis, N.P., Schnoor, J.L., and Georgakakos, K.P., 1989, Modeling of long-term lake alkalinity responses to acid deposition: Journal of Water Pollution Control, v. 61, p. 188-199.

OrTh, C.J., Gilmore, J.S., Knight, J.D., PIllmore, C.L., Tschudy, R.H., and FASSETT, J.E., 1981, An iridium abundance anomaly at the palynological Cretaceous-Tertiary boundary in northern New Mexico: Science, v. 214, p. 1341-1343.

Pierazzo, E., Hahmann, A.N., and Sloan, L.C., 2003, Chicxulub and climate: radiative perturbations of impact-produced S-bearing gases: Astrobiology, v. 3, p. 99-118.

Pierazzo, E., Kring, D.A., and Melosh, J.H., 1998, Hydrocode simulation of the Chicxulub impact event and the production of climatically active gases: Journal of Geophysical Research, v. 103, p. $28,607-28,625$.

Pillmore, C.L., Flores, R.M., and Fleming, F., 1988, Field guide to the continental Cretaceous-Tertiary boundary in the Raton Basin, Colorado and New Mexico: in Holden, G.S., ed., Geological Society of America Field Trip Guidebook, Centennial Meeting, p. $227-258$.

PinTo, J.P., Turco, R.P., and Toon, O.B., 1989, Self-limiting physical and chemical effects in volcanic eruption clouds: Journal of Geophysical Research, v. 94, p. 11,156-11,174.

PoPE, K.O., BAINEs, K.H., OCAMPO, A.C., and Ivanov, B.A., 1994, Impact winter and the Cretaceous/Tertiary extinctions: results of a Chicxulub impact model: Earth and Planetary Science Letters, v. 128 , p. 719-725.

PospiCHAL, J.J., 1996, Calcareous nannoplankton mass extinction at the Cretaceous/Tertiary boundary: an update: in Ryder, G., Fastovsky, D., and Gartner, S., eds., The Cretaceous-Tertiary Event and Other Catastrophes in Earth History: Geological Society of America Special Paper 307, p. 335-360.

Preisinger, A., Aslanian, S., Brandstätter, F., Grass, F., StrandNER, H., and Summesberger, H., 2002, Cretaceous-Tertiary profile, rhythmic deposition, and geomagnetic polarity reversal of marine sediments near Bjala, Bulgaria: in Koeberl, C., and MacLeod, K., eds., Catastrophic Events and Mass Extinctions: Impacts and Beyond: Geological Society of America Special Paper 356, p. $213-229$.

PRINN, R.G., and Fegley, B., JR., 1987, Bolide impacts, acid rain, and biosperic traumas at the Cretaceous-Tertiary boundary: Earth and Planetary Science Letters, v. 83, p. 1-15.

RETALlaCK, G.J., 1996, Acid trauma at the Cretaceous-Tertiary boundary in eastern Montana: GSA Today, v. 6, p. 2-7.

Rosseland, B.O., 1986, The influence of acidic pond water on amphibians: a review: Water, Air, and Soil Pollution, v. 30, p. 451460.

SchindLER, D.W., 1988, Effects of acid rain on freshwater ecosystems: Science, v. 239, p. 149-157.

Schindler, D.W., Mills, K.H., Malley, D.F., Findlay, D.L., ShearER, J.A., DAvies, I.J., Turner, M.A., Linsey, G.A., and CruiKSHANK, D.R., 1985, Long-term ecosystem stress: the effects of years of experimental acidification of a small lake: Science, v. 228, p. 1395-1401.

SCHNOOR, J.L., and STUMm, W., 1985, Acidification of aquatic and terrestrial systems: in Stumm, W., ed., Chemical Processes in Lakes: Wiley-Interscience, New York, p. 311-338.

SheEhan, P.M., and FASTOVSky, D.E., 1992, Major extinctions of land-dwelling vertebrates at the Cretaceous-Tertiary boundary, eastern Montana: Geology, v. 20, p. 556-650.

SigNOR, P.W., III, and LIPPS, J.H., 1982, Sampling bias, gradual extinction patterns and catastrophes in the fossil record: in Silver, L.T., and Schultz, P.H., eds., Geological Implications of Impacts of Large Asteroids and Comets on the Earth: Geological Society of America Special Paper 190, p. 291-296.

Sigurdsson, H.S., D'HondT, S., and CAREY, S., 1996, The impact of the Cretaceous/Tertiary bolide on evaporite terrain and the generation of major sulfuric acid aerosol: Earth and Planetary Science Letters, v. 109, p. 543-559.

SMIT, J., 1982, Extinction and evolution of planktonic foraminifera af- 
ter a major impact at the Cretaceous/Tertiary boundary: Geological Society of America Special Paper 190, p. 329-352.

SwANSON, K.M., and VAN DER LINGEN, G.J., 1994, Podocopid ostracod dissolution-description of a new paleoenvironmental tool, with examples from the eastern Tasman Sea: in Van Der Lingen, G.J., Swanson, K.M., and Muir, R.J., eds., Evolution of the Tasman Sea Basin: Balkema, Rotterdam, p. 245-260.

SwANSON, K.M., and VAN DER LINGEN, G.J., 1997, Late Quaternary ostracod and planktonic foraminiferal dissolution signals from the eastern Tasman Sea-palaeoenvironmental implications: Palaeogeography, Palaeoclimatology, Palaeoecology, v. 131, p. 303-314.

SweEt, A.R., and Braman, D.R., 1992, The K/T boundary and contiguous strata in western Canada: interactions between paleoenvironments and palynological assemblages: Cretaceous Research, v. 13, p. 31-79.

SwiSHER, C.C., III, Dingus, L., and BuTLER, R.F., $1993,{ }^{40} \mathrm{Ar} /{ }^{39} \mathrm{Ar}$ dating and magnetostratigraphic correlation of the terrestrial Cretaceous-Paleogene boundary and Puercan Mammal Age, Hell Creek-Tullock formations, eastern Montana: Canadian Journal of Earth Sciences, v. 30, p. 1981-1996.

ULRICH, B., 1983, Soil acidity and its relations to acid deposition: in Ulrich, B., and Pankrath, J., eds., Effects of Accumulation of Air Pollutants in Forest Ecosystems: D. Reidel Publishing Company, Dordrecht, p. 127-146.

VAJDA, V., RAINE, I., and Hollis, C., 2001, Indication of global deforestation at the Cretaceous-Tertiary Boundary by New Zealand fernspike: Science, v. 294, p. 1700-1702.

ViCKERY, A.M., KRING, D.A., and MeLosh, H.J., 1992, Ejecta associ- ated with large terrestrial impacts: implications for the Chicxulub impact and K/T boundary stratigraphy: Lunar and Planetary Science, v. 23, p. 1473-1474.

VonHof, H.B., and SMiT, J., 1997, High-resolution Late Maastrichtian-early Danian oceanic ${ }^{87} \mathrm{Sr} /{ }^{86} \mathrm{Sr}$ record: implications for Cretaceous-Tertiary boundary events: Geology, v. 25, p. 347-350.

WetzeL, R.G., 1983, Limnology, 2nd edition: Saunders College Publishing, Philadelphia, $209 \mathrm{p}$.

Wilson, R.W., Bergman, H.L., and Narahara, A., 1999, Ion and acid-base balance in three species of Amazonian fish during gradual acidification of extremely soft water: Physiological and Biochemical Zoology, v. 72, p. 277-285.

Wright, R.F., Dale, T., GJessing, E.T., Hendrey, G.R., Henriksen, A., Johannessen, M., and Muniz, I.P., 1975, Impact of acid precipitation on freshwater ecosystems in Norway: Water, Air, and Soil Pollution, v. 6, p. 483-499.

YANG, W., and AHRENS, T.J., 1998, Shock vaporization of anhydrite and global effects of the K/T bolide: Earth and Planetary Science Letters, v. 156, p. 125-140.

Ye, C.H., 1994, Succession of Cypridacea (Ostracodea) and nonmarine Cretaceous stratigraphy of China: Cretaceous Research, v. 15, p. $285-304$.

ZAHNLE, K.J., 1990, Atmospheric chemistry by large impacts: in Sharpton, V.L., and Ward, P.D., eds., Global Catastrophes in Earth History: An Interdisciplinary Conference on Impacts, Volcanism, and Mass Mortality: Geological Society of America Special Paper 247, p. 271-288.

ACCEPTED JANUARY 13, 2005

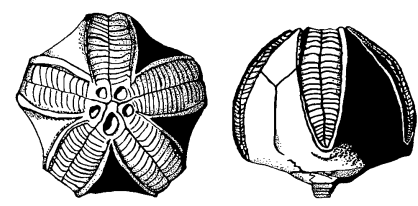

